\title{
Sexual development and maturity scale for the angel shark Squatina squatina (Elasmobranchii: Squatinidae), with comments on the adequacy of general maturity scales
}

\author{
Filip Osaer ${ }^{1,2,3, *}$, Krupskaya Narváez ${ }^{1,2,3}$, José G. Pajuelo² ${ }^{2}$ José M. Lorenzo² \\ ${ }^{1}$ ELASMOCAN, Asociación Canaria para la Investigación y Conservación de los Elasmobranquios, \\ 35001 Las Palmas de Gran Canaria, Spain \\ ${ }^{2}$ Departamento de Biología, Universidad de Las Palmas de Gran Canaria, Edificio de Ciencias Básicas, Campus de Tafira, \\ 35017 Las Palmas de Gran Canaria, Spain \\ ${ }^{3}$ Fundación Colombiana para la Investigación y Conservación de Tiburones y Rayas, SQUALUS, Carrera 60A No 11-39, Cali, \\ Colombia
}

\begin{abstract}
This paper contributes to the reproductive biology of the genus Squatina and aims to complement the criteria, uniformity and adaptable staging of sexual maturity scales for elasmobranchs based on data from the angel shark $S$. squatina captured near the island of Gran Canaria (Canary Islands, Central-East Atlantic). Both sexes presented a paired reproductive tract with both sides active and asymmetric gonad development. Microscopic and macroscopic observations of the testes were consistent and indicated seasonality of spermatogenesis. The spermatocyst development pattern in mature individuals could not be assigned to any of the categories described in the literature. The ovaries-epigonal organ association was of the external type. Although all Squatinidae share a conservative morphology, they show differences across species in the functionality of the paired reproductive tract, seasonality of spermatogenesis, coiled spermatozoa and the presence of egg candles. A flexible classification technique was used to describe an illustrated 5 -stage sexual maturity scale using an ontogenic approach, assessable by macroscopic condition indices. The phases include juvenile, subadult, developing, active/pregnant and spent/post-partum in males and females, respectively. Claspers were considered calcified when it was necessary to break a clasper when bending the axial cartilage $180^{\circ}$ over its longitudinal axis. Recent general maturity scale proposals for elasmobranchs could not be adapted. The interspecific variations in fish development, which do not facilitate a standard terminology across all fishes, indicate the need for species-specific and adaptable macroscopic and microscopic staging schema, rather than using generalized classification systems.
\end{abstract}

KEY WORDS: Reproductive biology · Elasmobranch • Macroscopic analysis · Histology · Viviparous · Lecithotrophy · Seasonality · Canary Islands

\section{INTRODUCTION}

The angel shark Squatina squatina, which has a lecithotrophic viviparous reproduction mode (Budker 1958, Capapé et al. 1990), is a bottom-dwelling species of the European and North African continental shelves (Ebert \& Stehmann 2013). Because of its life

\footnotetext{
${ }^{*}$ Corresponding author: filip@elasmocan.org
}

history characteristics and bycatch in fisheries with steadily increasing effort and capacity, its abundance has dramatically declined during the past $50 \mathrm{yr}$ (Morey et al. 2006). The species is considered extinct in the North Sea (ICES 2005, 2014) and Critically Endangered in its remaining range, with the possible exception of some areas of the southern Mediterran-

() The authors 2015. Open Access under Creative Commons by Attribution Licence. Use, distribution and reproduction are unrestricted. Authors and original publication must be credited. 
ean and the Canary Islands, where its status must be confirmed and conservation measures should be introduced as a matter of urgency (Morey et al. 2006, ICES 2014). Despite concerns regarding the conservation status of this species, limited information is available about its life history parameters. For example, the only study on the reproductive biology of $S$. squatina was by Capapé et al. (1990) along the Tunisian coast.

Investigating chondrichthyan population dynamics requires detailed information regarding the reproductive biology of a species, including clear definitions for distinguishing between maturity phases, timing of ovulation and periodicity of gestation and parturition (Walker 2005). Precise and clear descriptions, including pictures, of the main characteristics of gonads in different stages are required to minimise mistakes in the assignment of maturity stages for the correct calculation of maturity ogives (ICES 2007). This level of detail is lacking for most elasmobranch species and for all species in the genus Squatina. Additionally, the maturity assessment criteria have not been consistent among the different studies of the genus. Most works considered a juvenile, subadult and mature phase in males and females based on the length and calcification of the clasper and on the condition of the ovaries, oviduct and oviducal gland, following Capapé et al. (1990) (Bridge et al. 1998, Capapé et al. 2002, 2005, Colonello et al. 2007). Other research only included a mature and an immature phase following the former criteria (Awruch et al. 2008) or with the distinction of an actively reproducing stage based on the condition of the epididymides and ova and uteri (Shelmerdine \& Cliff 2006), as well as sperm smears (Natanson \& Cailliet 1986). In contrast, Baremore (2010) based maturity determination on conditions described by Walker (2005) and on secondary characteristics and arbitrary size criteria for follicles and for nidamental glands, respectively. The study by Natanson \& Cailliet (1986) is the only study that considered 5 maturity phases in females: juvenile, subadult, mature, reproductively active and post-partum based on the condition of the ovaries, the size of the follicles and oviducts and the number of ova or embryos. However, the size range of follicles between 10 and $50 \mathrm{~mm}$ is not covered in the description.

The importance and the need to standardise criteria used to assess elasmobranch reproductive development and to maintain a level of consistency between studies has been noted in recent years (Stehmann 2002, Walker 2005). Stehmann (2002) described maturity phases based on descriptions of the reproductive tract with 2 immature and mature phases for males. Similarly, for females, 2 immature phases were described, and 4 and 5 phases based on either the ovarian or uterine activity for oviparous and viviparous species, respectively. Walker (2005) introduced condition indices of different organs from the reproductive tract with a key for immature or mature phase assumption only. Brown-Peterson et al. (2011) highlighted the need for unified terminology and described a conceptual model for reproductive development and a maturity scale with a corresponding terminology for all fishes that was based on micro- and macroscopic observations from teleosts. However, reviews on fish reproduction have revealed inconsistencies in this proposal, especially regarding the definition of an ovarian follicle. Additionally, interspecific variations in fish oocyte development do not lend themselves to a standard terminology across all fishes. Therefore, a staging schema for oocyte development needs to be adaptable to species' variations (Grier 2012). The most recent proposals of general maturity scales for elasmobranchs, viz. ICES $(2010,2013)$, and the studies from the reproductive biology of a viviparous and oviparous elasmobranch species of Paiva et al. (2011) and SerraPereira et al. (2011), respectively, affirmed having consistently adopted the proposed terminology of Brown-Peterson et al. (2011). Despite this, all mentioned studies showed differences with the conceptual model and terminology proposed by BrownPeterson et al. (2011). To this end, the specific objectives of the current study were to (1) establish a comprehensive and illustrated maturity scale that is based on unambiguous condition indices from macroscopic observations and that is based on standardised methods for elasmobranch reproduction studies, (2) confirm the macroscopic testes observations using histology and (3) compare the spermatocyst development pattern with the described categories in the literature.

\section{MATERIALS AND METHODS}

Angel sharks were collected from incidental captures from the coastal artisanal fishery on the island of Gran Canaria (Canary Islands) between 2007 and 2009. During the sampling, the presence of fluids in the seminal vesicles and the clasper glands was recorded. Fluids were analysed for fertility under a stereoscopic microscope. All specimens were then deep-frozen for later analysis in the laboratory. The thawing process was controlled over approximately 


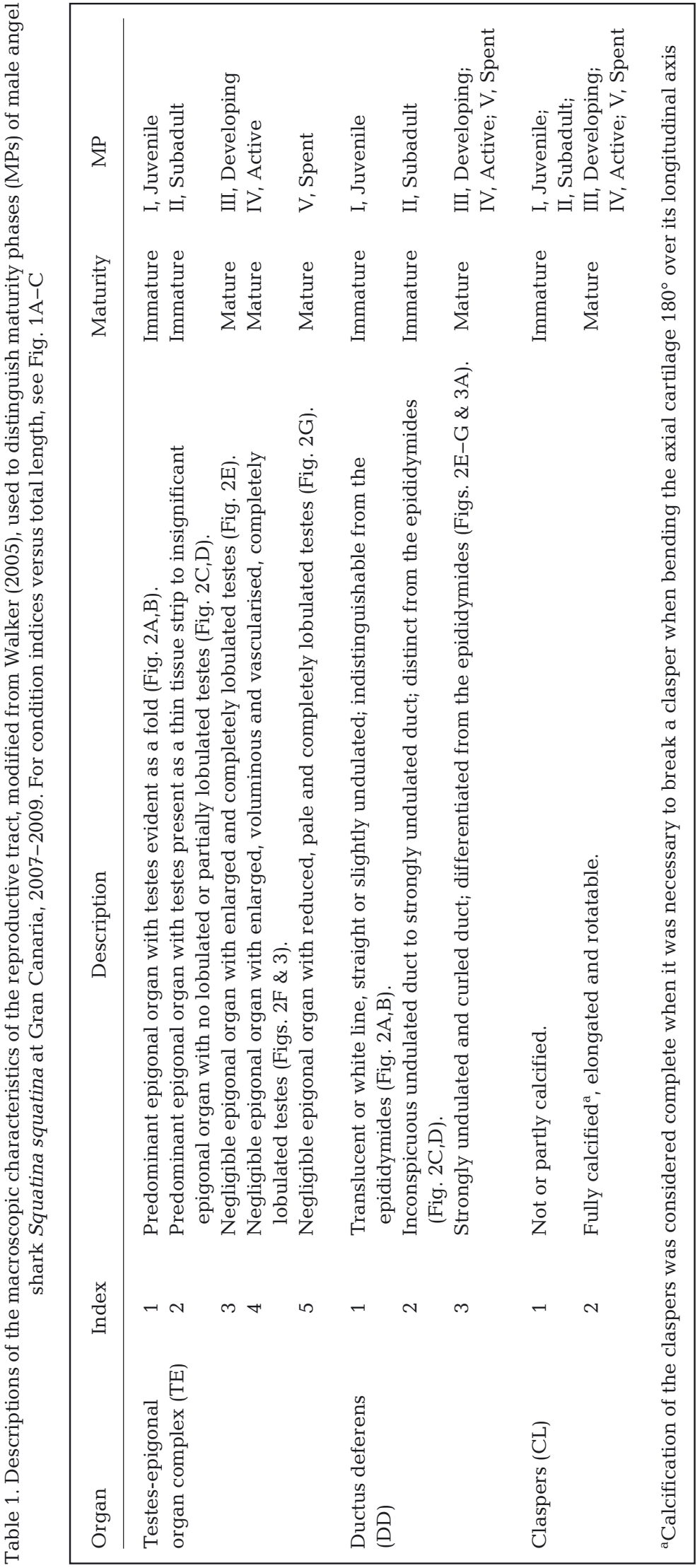

$12 \mathrm{~h}$ by insulating the individuals. Biometric measurements were taken to the nearest $\mathrm{mm}$ : the total length from the tip of the snout to the ventral tip of the caudal fin, the diameter of follicles containing vitellogenic oocytes, and the maximum length and width of the testes-epigonal organ complex (TE), ovaries-epigonal organ complex (OE) and uteri. The condition of the reproductive tract was recorded based on macroscopic observations. These results were then assigned to condition classes that were modified from Walker (2005), who had a concise description and provided sufficient distinctions between the different conditions. In males, the development of the TE, ductus deferens and claspers (elongation, rotation and calcification according to Clark \& von Schmidt 1965) were considered according to the terminology of Hamlett (1999). The calcification of the claspers was considered complete when it was necessary to break a clasper when bending the axial cartilage $180^{\circ}$ over its longitudinal axis. In females, the development and the condition of the $\mathrm{OE}$, oviducal glands, uteri and cervix were considered according to the terminology of Hamlett et al. (2005) for the oviduct sections. The established condition indices were allocated to maturity phases, with terminologies adapted from Stehmann (2002) and Walker (2005) or from BrownPeterson et al. (2011) when the previous works did not provide an outcome. The assignment of the maturity phases was modified from the conceptual model of Brown-Peterson et al. (2011) and follows ontogeny; the immature phases can only occur once during the maturation development of the individual, and the 3 mature phases are parts of the reproductive cycle. The term 'phase' was used to describe parts of the maturity development and the cyclical reproductive process, and 'stage' was used to describe development within a phase. Five different phases could be distinguished in males and females, with 2 immature phases and 3 mature phases (Tables $1 \& 2$ ). After dissection of the gonads and macroscopic analysis, the TE was fixed in $4 \%$ buffered formaldehyde ( $\mathrm{pH} 7$ ) for later histological analysis. 


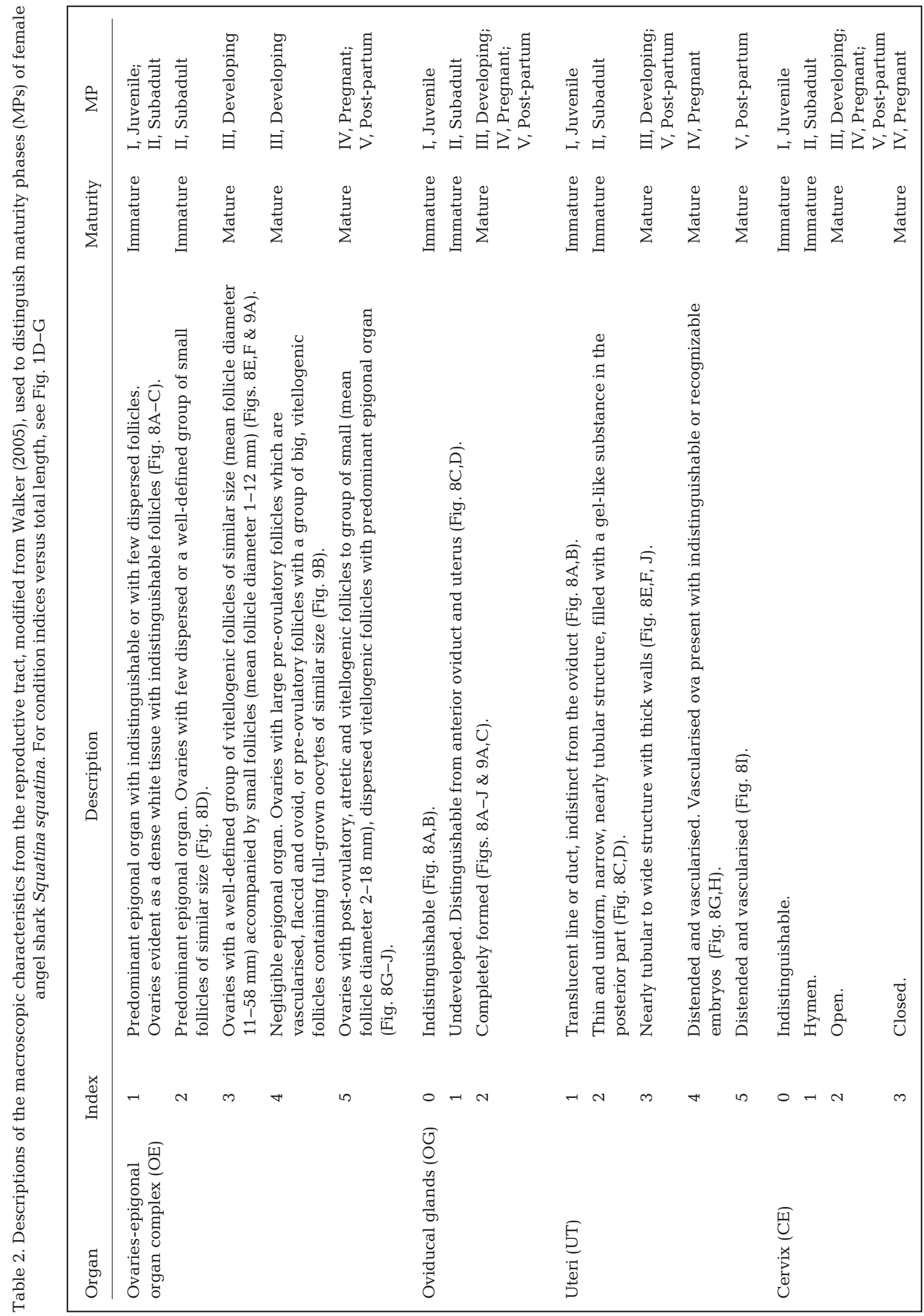


The measured diameters were averaged per ovary to obtain the mean follicle diameter. Asymmetric beanplots (Kampstra 2008) were used to visualize the density distributions and ranges of the left and right reproductive tract measurements with the free software for statistics R (R Core Team 2014).

The microscopic analysis of testes was used to corroborate the macroscopic observations and, simultaneously, to determine the spatial pattern formed by spermatocysts in successive stages of development according to the categories described by Pratt (1988). Transverse cross sections of the left and right testis were obtained from the anterior, middle and posterior areas. These sections were dehydrated in ethanol solutions, cleared in xylol and embedded in paraffin, and $5 \mu \mathrm{m}$ slices were stained in haematoxylin-eosin solution. The terminology applied in the histology descriptions followed that of Engel \& Callard (2005). The macroscopic analysis of the OE was used to determine the type of epigonal-ovarian association according to the descriptions of Pratt (1988).

\section{RESULTS}

From January 2007 to January 2009, 313 angel sharks (146 males and 167 females) that ranged between 24.8 and $120.8 \mathrm{~cm}$ total length were examined. Five maturity phases (MPs) were adopted based on the observed conditions: I, juvenile (immature); II, subadult (immature); III, developing (mature); IV, active/ pregnant (mature); and V, spent/post-partum (mature) (Tables 1 \& 2, Fig. 1). In males, 16 juveniles (24.8$62.1 \mathrm{~cm}), 36$ subadults $(67.1-105.2 \mathrm{~cm}), 13$ developing
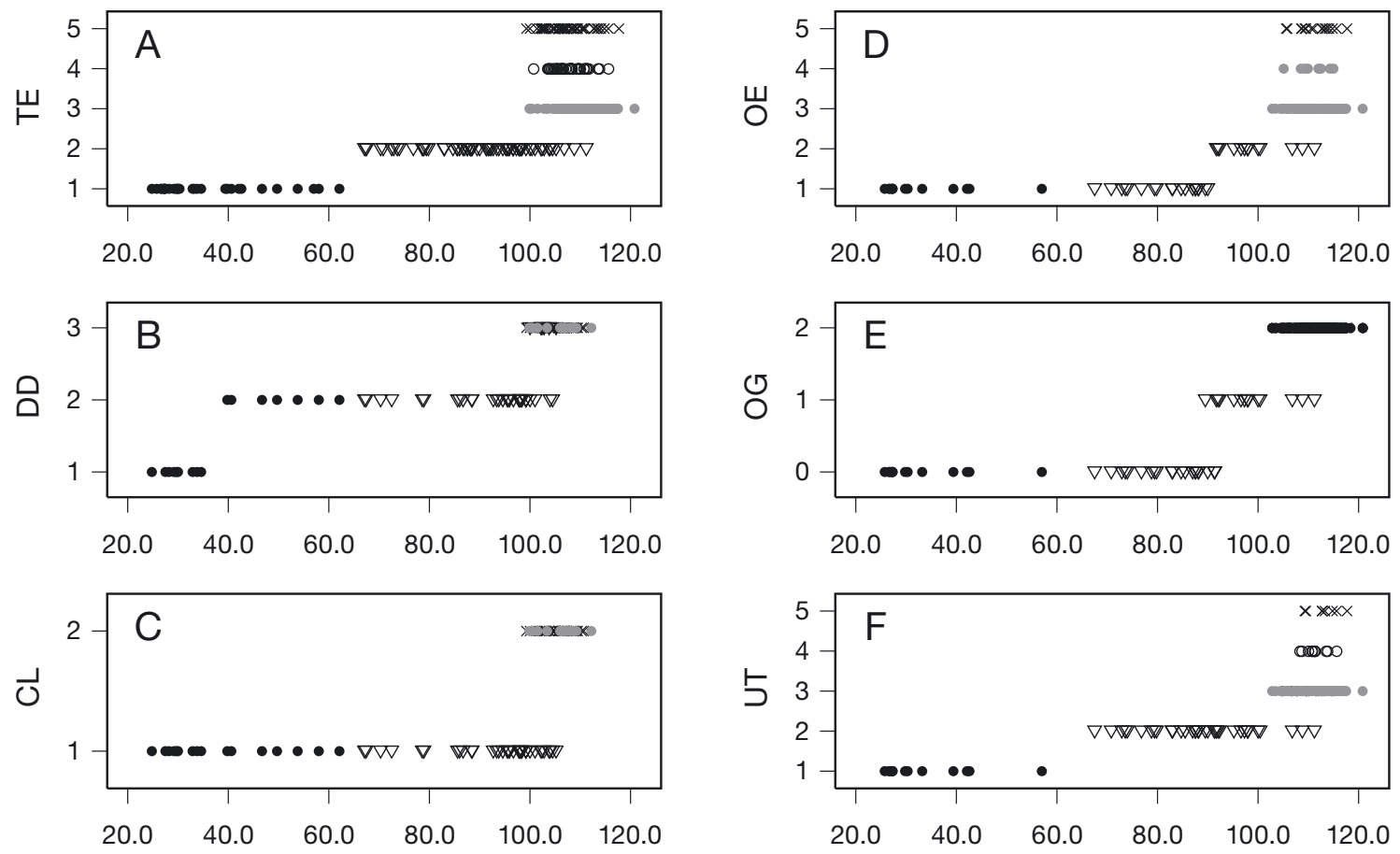

- Juvenile

$\nabla$ Subadult

- Developing

- Active / Pregnant

$\times$ Spent / Post-partum

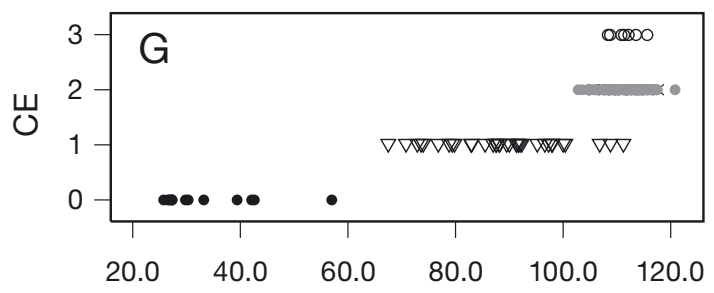

Total length $(\mathrm{cm})$

Fig. 1. Total length versus condition indices of (A) testes-epigonal organ complex (TE), (B) ductus deferens (DD), (C) claspers (CL), (D) ovaries-epigonal organ complex (OE), (E) oviducal glands (OG), (F) uteri (UT) and (G) cervix (CE) for angel shark Squatina squatina at Gran Canaria, 2007-2009. For detailed descriptions of the condition indices of reproductive tract organs in males and females, see Tables $1 \& 2$ 
(99.9-112.2 cm), 42 active (100.7-111.7 cm) and 39 spent $(99.3-110.7 \mathrm{~cm})$ individuals were analysed. In females, 13 juveniles $(25.8-57.0 \mathrm{~cm}), 35$ subadults $(67.5-111.2 \mathrm{~cm}), 89$ developing $(102.8-120.8 \mathrm{~cm}), 11$ pregnant (108.3-115.6 cm) and 16 post-partum (105.6$117.7 \mathrm{~cm}$ ) individuals were analyzed. Three pregnant $(\mathrm{MP}=\mathrm{IV})$ females presented uteri with partially or fully aborted content. Three females were excluded from the analysis; one female presented damaged ovaries, and two did not fit the described scale. The juvenile phase shows no significant development of the reproductive tract. The subadult phase encompasses the progress of the reproductive tract to complete maturity. The developing phase is marked by gonadal growth towards active reproduction in mature individuals. The active phase in males and the pregnant phase in females include the active reproduction process. The spent phase in males and the post-partum phase in females indicate the completion of the reproductive cycle with no sexual activity or gonadal growth towards active reproduction.

\section{Male reproductive tract}

The male reproductive tract presented paired TE, epididymides, ductus deferens, seminal vesicles and claspers. The TE was suspended from the dorsal surface of the anterior peritoneal cavity by double mesorchia, which laterally connect to the interior of the epididymides. The epigonal organ was mainly observed as a thin tissue that covered the proximal end of the testis over its complete length. The testes were whitish, elongated, slightly dorsoventrally flattened, tapered at both ends and had a lobed appearance due to the meandering of the tissue. In the centre of the distal end, a slight sinuously pre-germinal fold ran along the length of the testes. Consequently, the germinal zone was principally located at a lateral extreme of a lobe, and its relative position to the epigonal organ varied over the length of the testes from opposite to beside and from proximate to in between 2 lobes. The epididymides covered all but the exterior border of the kidneys, and the head, which was distinctive with its tightly coiled finer tubules, extended over the kidneys (Figs. 2E-G \& 3). During the juvenile phase $(\mathrm{MP}=\mathrm{I})$, the TE presented as a predominant epigonal organ with testes evident as a fold $(\mathrm{TE}=1$, see Table 1; Figs. 1A \& 2A,B). The ductus deferentes were observed as a straight translucent line during the early development stage (Fig. 2A), and as a partially and slightly undulated white line from $39.8 \mathrm{~cm}$ total length $(\mathrm{DD}=1$; Figs. $1 \mathrm{~B}$
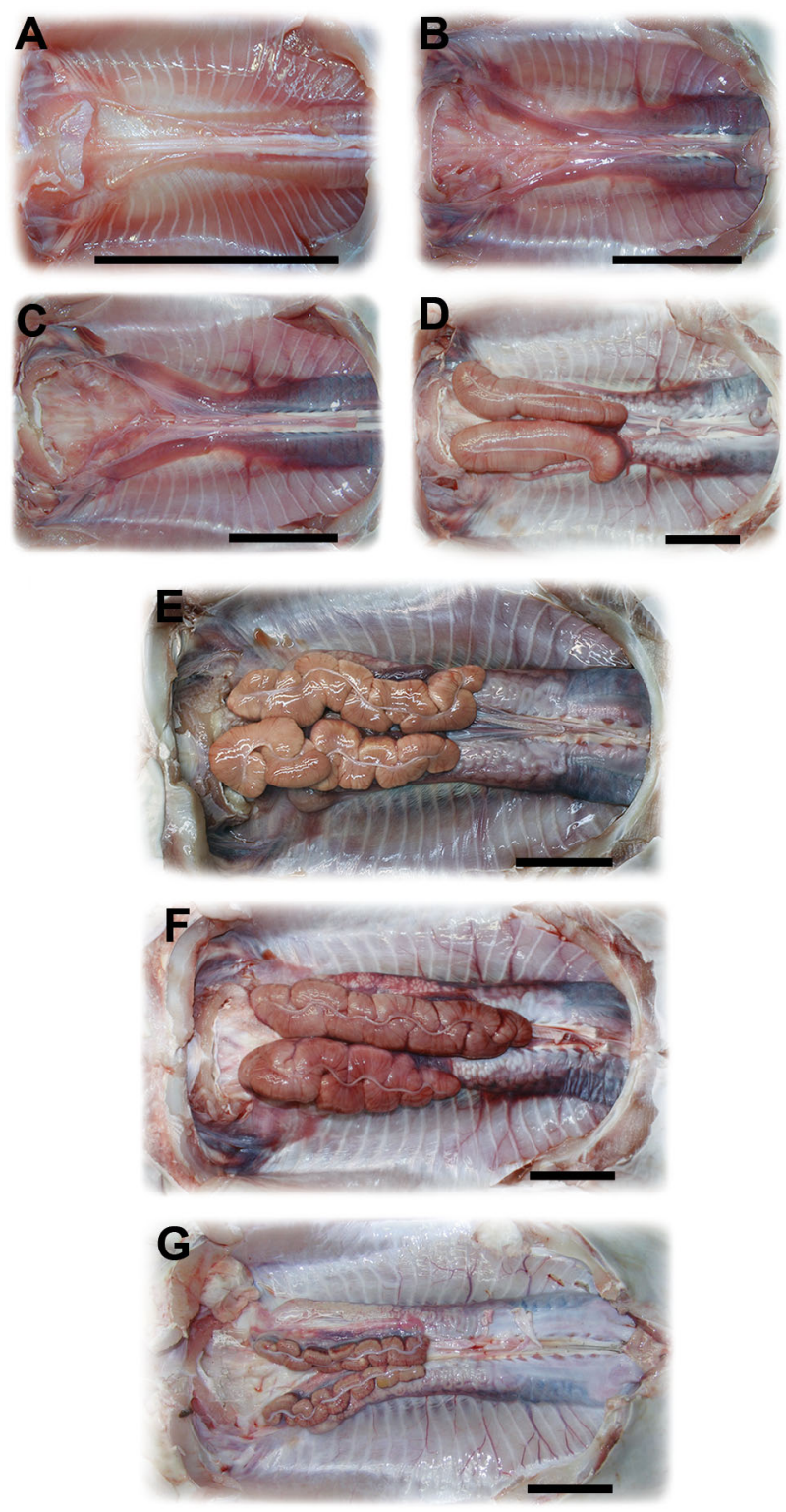

Fig. 2. Male angel shark Squatina squatina reproductive tract development per maturity phase (MP). I, juvenile (immature) in (A) early and (B) late stage. II, subadult (immature) in (C) early and (D) late stage. (E) III, developing (mature). (F) IV, active (mature). (G) V, spent (mature). Left side is anterior of the specimen. Epididymides, ductus deferens and seminal vesicles are extra-peritoneal. For details and terminology of the major portions of the reproductive tract and MPs see Fig. 3 and Table 1. Scale bars $=5 \mathrm{~cm}$

$\& 2 \mathrm{~B})$. The claspers were only visible as small tips. In the subadult phase (MP = II), testes development was evident from $67.1 \mathrm{~cm}$ total length as a thin tissue strip with a distinct pre-germinal fold (Fig. 2C). In the late stage, the predominant epigonal organ became insignificant and the testes began lobulating $(\mathrm{TE}=2$; 

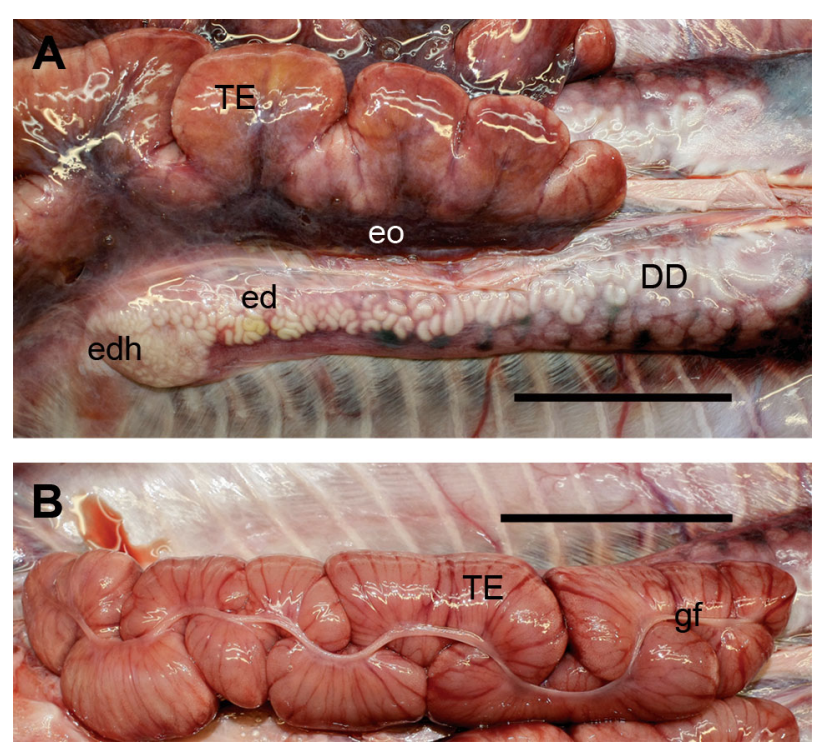

Fig. 3. Details of the reproductive tract of male angel shark Squatina squatina. In the active maturity phase (IV) with a negligible epigonal organ (eo), completely lobulated, whitish, elongated, voluminous, vascularised, and slightly dorsoventrally flattened testes, tapered at both ends $(\mathrm{TE}=4$, see Table 1 for categories and condition indices), and strongly undulated ductus deferens ( $\mathrm{DD}=2$ ). (A) Transversal view of the proximal part of the testis-epigonal organ complex (TE), epididymis head (edh), epididymis (ed), and ductus deferens (DD) of the right reproductive tract. The testes have a lobed appearance due to the meandering of the tissue. (B) Relative position of the pre-germinal fold (gf) to the testis lobes. The germinal zone is principally located at a lateral extreme of a lobe, and its relative position to the epigonal organ varies over the length of the testis from opposite to beside and from proximate to in between 2 lobes. Left side is anterior of the specimen. For illustrations of the development and terminology of the major portions of the reproductive tract and maturity phases, see Fig. 2 and Table 1 . Scale bars $=5 \mathrm{~cm}$

Figs. 1A \& 2D). The length of the TE varied between 49 and $160 \mathrm{~mm}$ (Fig. 4A), and its width between 7 and $37 \mathrm{~mm}$ (Fig. 4B). The undulating of the inconspicuous ductus deferens differentiated from the epididymides during the early stage (Fig. 2C) and developed to a strongly undulated duct during the late stage ( $\mathrm{DD}=2 ;$ Figs. $1 \mathrm{~B} \& 2 \mathrm{D})$. The claspers elongated without or with partial calcification (Fig. 1C). In mature individuals (MP = III, IV and V), the size, lobulation and morphology of the developed TE fluctuated with the maturity phase from highly vascularised and voluminous $(\mathrm{TE}=4)$ during the active phase $(\mathrm{MP}=$ IV) to reduced and pale $(\mathrm{TE}=5)$ during the spent

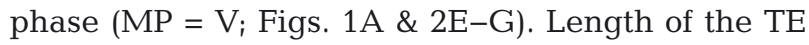
varied between 79 and $181 \mathrm{~mm}$ (Fig. 4A), and its width between 12 and $57 \mathrm{~mm}$ (Fig. 4B). The ductus deferens was strongly undulated and curled $(\mathrm{DD}=3)$, and the meandering was less pronounced towards

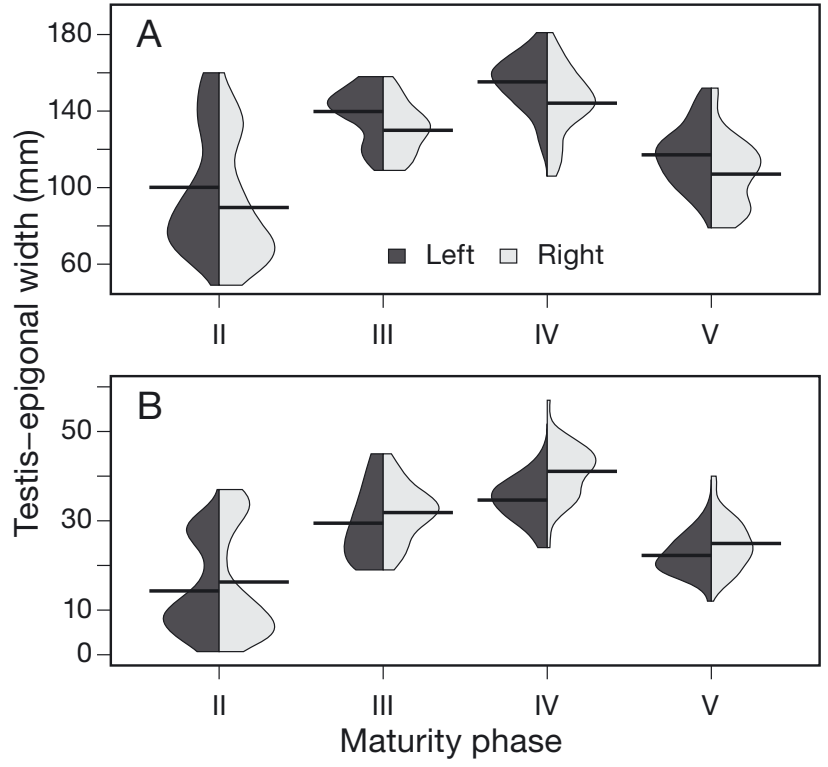

Fig. 4. Maturity phase versus density plots of the maximum left and right testis-epigonal organ complex (A) length and (B) width for angel shark Squatina squatina. Horizontal bars represent the mean value per size distribution. Maturity phases: II, subadult (immature); III, developing (mature); IV, active (mature); V, spent. For illustrations of the development and terminology of the major portions of the reproductive tract and maturity phases, see Fig. 2 and Table 1

the seminal vesicles (Figs. 1B, 2E-G, \& 3A). Claspers were elongated, fully calcified and rotatable $(\mathrm{CL}=2)$ from $99.3 \mathrm{~cm}$ total length (Fig. 1C). In active males $(\mathrm{MP}=\mathrm{IV})$, helical shaped spermatozeugmata were found in the whitish fluids extracted from the seminal vesicles (Fig. 5A), whereas none were observed in the whitish secretions from the clasper glands (Fig. 5B). In mature (MP = III, IV and V) and late subadults (MP = II), the whitish secretions from the clasper glands were observed throughout the year, being more abundant in active males (MP $=$ IV). Bleeding or swollen claspers were not registered.

\section{Histology of the TE}

The macroscopic testes observations were consistent with those observations obtained through histological analysis. The spermatocyst development pattern could not be assigned to any of the 3 described categories. The following main spermatocyst stages were observed: spermatogonial (premeiotic; Fig. 6A), spermatocyte (meiotic; Fig. 6B), spermatid (postmeiotic; Fig. 6C) and spermatozoa (Fig. 6D). All stages of spermatogenesis were present in the late subadult $\left(\mathrm{MP}=\mathrm{II}_{\text {; Fig. }}\right.$ 7A), developing $(\mathrm{MP}=\mathrm{III})$ and active 

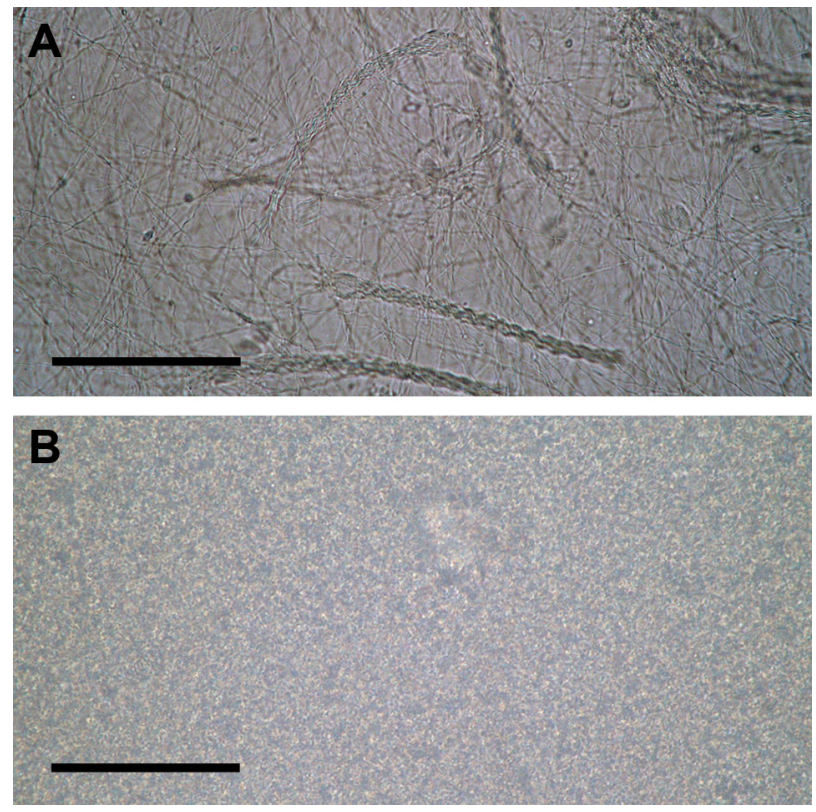

Fig. 5. Structure of secretions extracted from male angel shark Squatina squatina in active maturity phase (IV) from (A) the seminal vesicle and (B) the clasper gland. Helical spermatozeugmata were only found in the fluids extracted from the seminal vesicles in active males, whereas none were observed in the secretions from the clasper glands. Scale bars $=100 \mu \mathrm{m}$

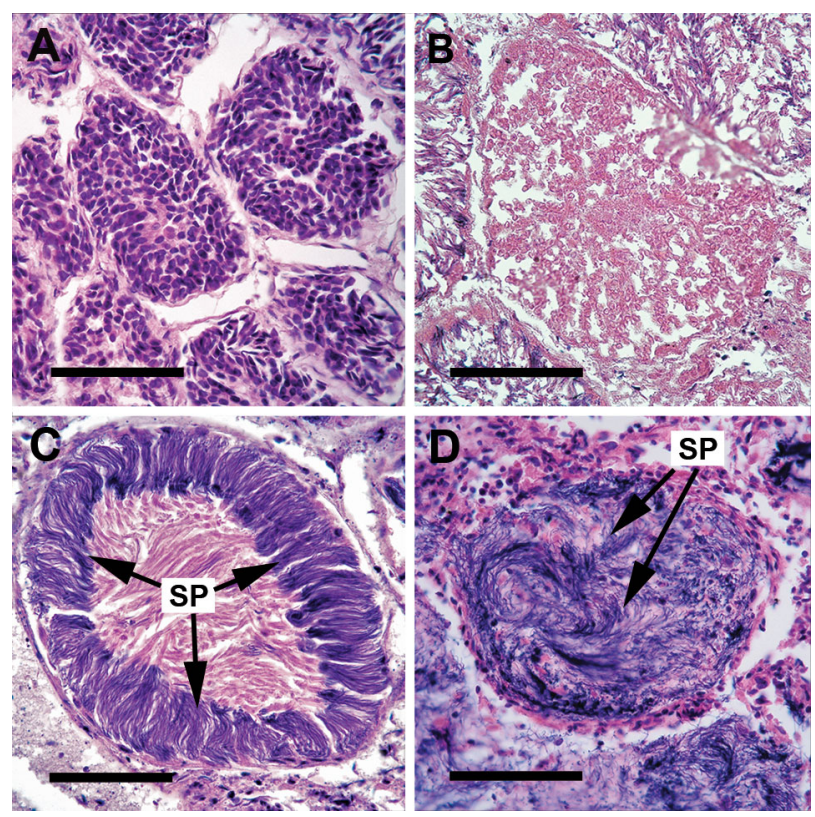

Fig. 6. Spermatocyst stages for angel shark Squatina squatina. (A) Spermatogonial stage (premeiotic). (B) Spermatocyte stage (meiotic). (C) Spermatid stage (postmeiotic), completion of spermiogenesis: cohorts of mature sperm (SP) within the spermatocysts. (D) Spermatozoa, mature sperm are released from the spermatocysts. Terminology of spermatogenesis development stages according to Engel \& Callard (2005). For spermatocyst development patterns per maturity phase, see Fig 6 . Scale bars $=100 \mu \mathrm{m}$
A

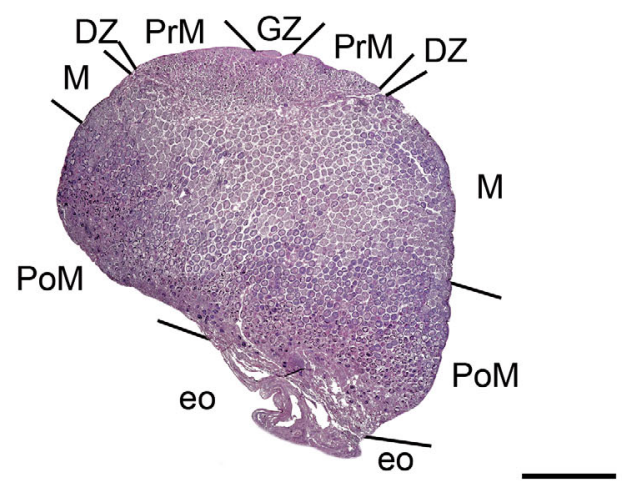

B

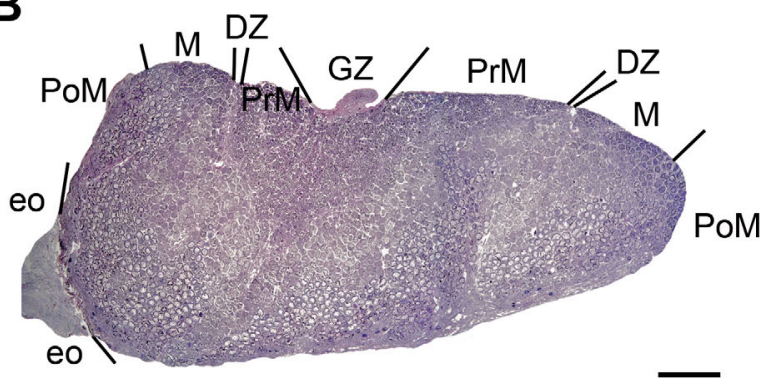

C

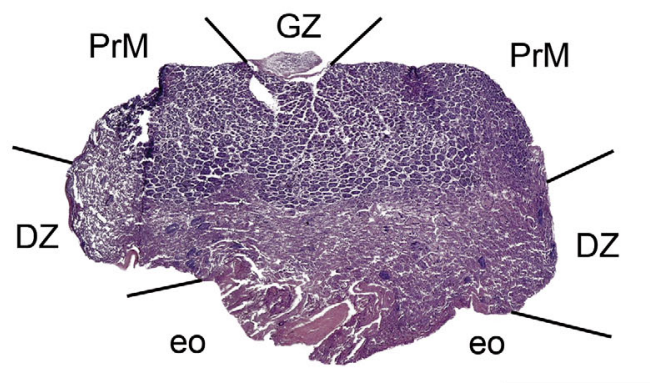

Fig. 7. Transverse testis sections, illustrating the spermatocyst development pattern in different maturity phases (MP) for angel shark Squatina squatina: (A) II, subadult (immature) in the late stage of development; (B) IV, active; and (C) $\mathrm{V}$, spent. Terminology of spermatogenesis development stages according to Engel \& Callard (2005): germinal zone (GZ), premeiotic zone (PrM), degenerate zone (DZ), meiotic zone $(\mathrm{M})$, postmeiotic zone (PoM) and epigonal organ (eo). The degenerate zone was predominant in the spent phase $(\mathrm{MP}=$ $\mathrm{V})$, whereas in the late subadult (MP = II) and active phase $(\mathrm{MP}=\mathrm{IV})$, the main part of the testis was occupied by the meiotic stage. For details of the spermatocyst stages, see Fig 6. For illustrations of the development and terminology of the major portions of the reproductive tract and MPs, see Fig. 2 and Table 1. Scale bars $=3 \mathrm{~mm}$

$(\mathrm{MP}=\mathrm{IV}$ ) phases (Fig. 7B). The degenerate zone was predominantly found in the proximal part of the testes in the spent phase ( $\mathrm{MP}=\mathrm{V}$; Fig. $7 \mathrm{C}$ ), whereas in the late subadult $(\mathrm{MP}=\mathrm{II})$, developing $(\mathrm{MP}=\mathrm{III})$ and active phase $(\mathrm{MP}=\mathrm{IV})$, the degenerate zone was present as a thin strip between the premeiotic and 
meiotic stage. In these maturity phases, the main part of the testis was occupied by the meiotic stage (Fig. 7A,B). Active males $(\mathrm{MP}=\mathrm{IV})$ manifested a much higher spermatogenesis activity compared to the late subadult (MP = II) and developing (MP = III) phases due to the larger volume of the testes. In spent males $(\mathrm{MP}=\mathrm{V})$, only the premeiotic stage was present, with a broad degenerate zone that gradually extended up to the epigonal organ after the disappearance of the meiotic phase. No differences in functionality were observed between the left and right testis.

\section{Female reproductive tract}

The female reproductive tract presented paired OE and oviducts. The oviducts were differentiated into the ostium, anterior oviduct, oviducal gland, oviduct and uterus. The oviducal gland was barrel-shaped and discharged directly into the uterus via a short oviduct. The uterus was constricted at its junction with the oviducal gland and separated from the cloaca at the posterior end by the cervix. Both OE were active and suspended from the dorsal surface of the anterior peritoneal cavity by double mesovaria. The epigonal organ was a dark red coloured connective tissue located at the proximal part of the complex. The ovaries-epigonal organ association was of the external type, with the follicles embedded in the ventral surface of the epigonal organ. Translucent or whitish follicles and ova were not observed (Figs. 8E-J \& 9). During the juvenile phase $(\mathrm{MP}=\mathrm{I})$, the oviducts were visible as a translucent line in the early development stage or a translucent duct in the late stage, with indistinct oviducal glands, uteri and cervix $(\mathrm{OG}=0$, $\mathrm{UT}=1, \mathrm{CE}=0$, see Table 2). The epigonal organ contained few dispersed follicles during the late stage, and the ovaries were visible as a dense white tissue with indistinguishable follicles (OE $=1$; Figs. 1D-G \& $8 \mathrm{~A}, \mathrm{~B})$. During the subadult phase $(\mathrm{MP}=\mathrm{II})$, the oviducts started developing from $67.5 \mathrm{~cm}$ total length and were visible as a thin, narrow, nearly tubular structure, filled with a gel-like substance in the posterior part of the uteri ( $\mathrm{UT}=2$ ), together with the presence of hymen ( $\mathrm{CE}=1$ ) in the cervix (Figs. 1G \& 8C). During the late stage, the oviducal glands became distinguishable from the anterior oviduct and uterus from $89.5 \mathrm{~cm}$ total length, but remained undeveloped $(\mathrm{OG}=2$; Figs. 1E \& 8D). A well-defined group of small follicles was observed in the ovaries $(\mathrm{OE}=2)$ from $91.7 \mathrm{~cm}$ total length (Figs. 1D \& 8D). The length of the OE varied between 35 and $110 \mathrm{~mm}$ (Fig. 10A), and its
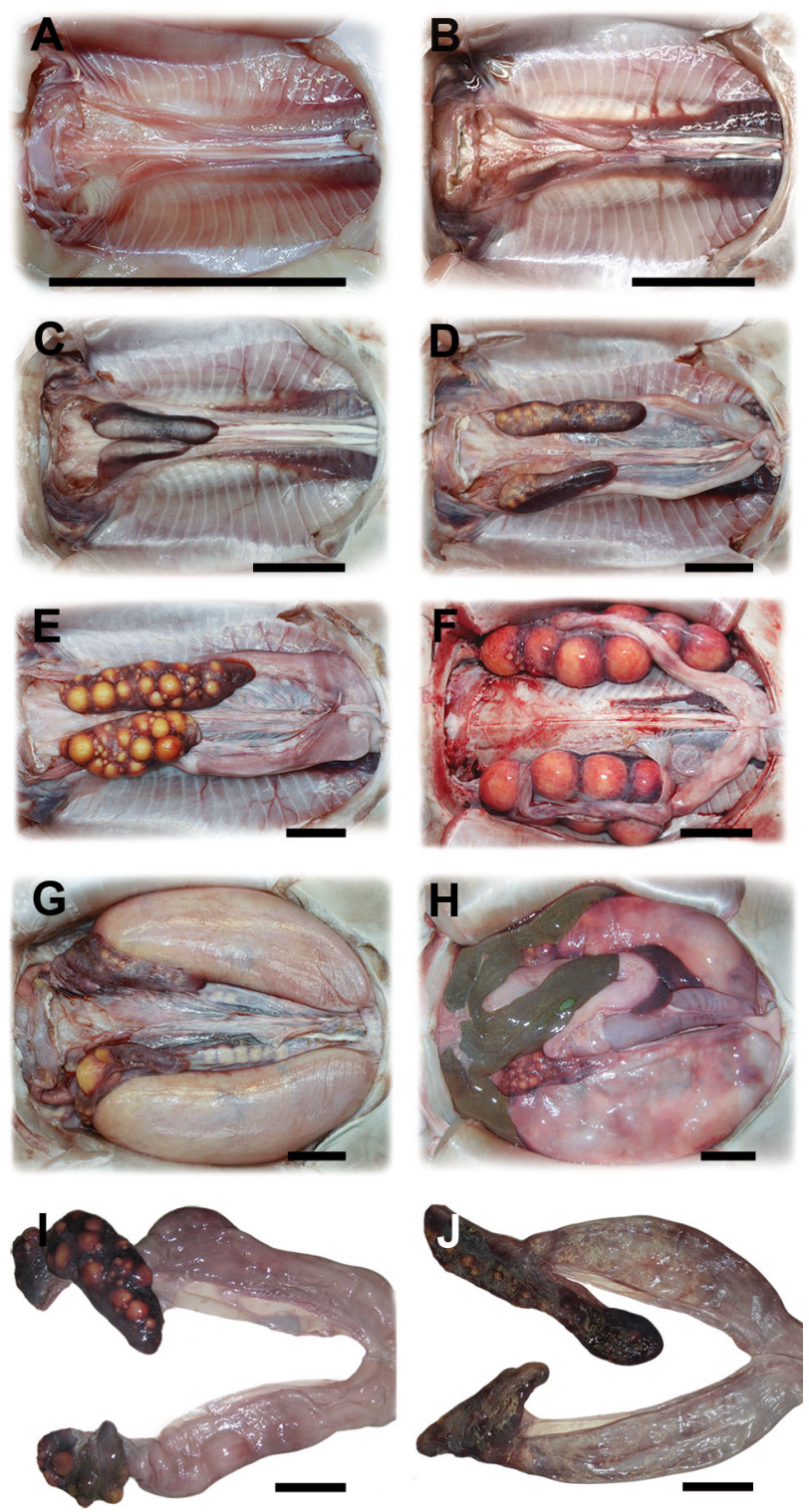

Fig. 8. Female angel shark Squatina squatina reproductive tract development per maturity phase (MP). I, juvenile (immature) in (A) early and (B) late stage. II, subadult (immature) in (C) early and (D) late stage. III, developing (mature) in $(E)$ early and $(F)$ late stage (ovaries-epigonal organ complex turned upside down to show oviducts). IV, pregnant (mature) in (G) early and $(\mathrm{H})$ late stage, with partial abortion of the left uterus. Liver and gastrointestinal tract are still present. V, post-partum (mature) in (I) early and (J) late stage. Left side is anterior of the specimen. For details and terminology of the major portions of the reproductive tract and MPs, see Fig. 9 and Table 2. Scale bars $=5 \mathrm{~cm}$

width between 13 and $26 \mathrm{~mm}$ (Fig. 10B). The length of the uterus varied between 55 and $102 \mathrm{~mm}$ (Fig. 11A), and its width between 7 and $30 \mathrm{~mm}$ (Fig. 11B). In mature individuals $(\mathrm{MP}=\mathrm{III}, \mathrm{IV}$ and V), the developed oviducal glands, uteri and OE fluctuated in size and 

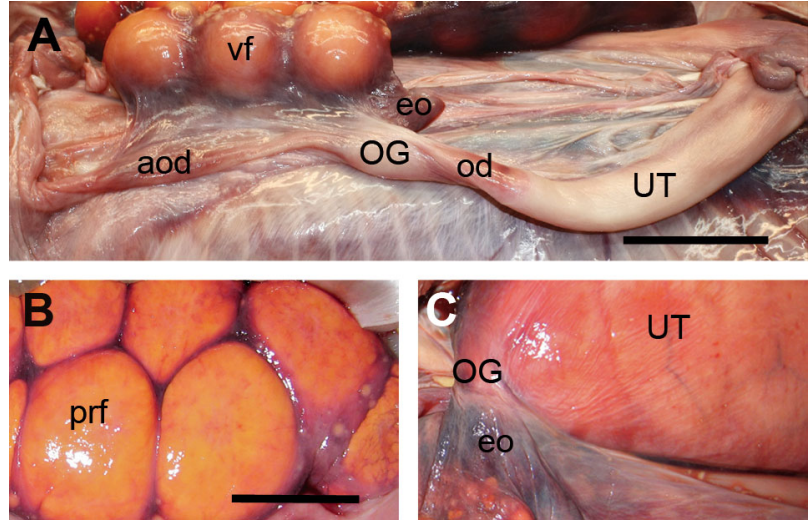

Fig. 9. Details of the reproductive tract of female angel shark Squatina squatina. (A) Transversal view of the right reproductive tract in maturity phase (MP) III (developing) with presence of a well-defined group of vitellogenic follicles (vf) of similar size accompanied by small follicles in the ovaries $(\mathrm{OE}=3$, see Table 2 for categories and condition indices), negligible epigonal organ (eo), anterior oviduct (aod), completely formed oviducal gland $(\mathrm{OG}=2)$, oviduct (od) and uterus (UT) as a nearly tubular structure (UT $=3$ ) with thick walls. (B) MP III (developing) with the presence of pre-ovulatory (prf), vascularised follicles in the ovaries $(\mathrm{OE}=4)$. (C) Condition of the oviducal gland and oviduct during MP IV (pregnant) with vascularised ova present in the uterus $(\mathrm{UT}=4)$. The oviducal gland is pushed towards the proximal part of the epigonal organ and the oviduct is not observable. Left side is anterior of the specimen. For illustrations of the development and terminology of the major portions of the reproductive tract and MPs, see Fig. 8 and Table 2. Scale bars $=5 \mathrm{~cm}$

morphology with the maturity phase. The length of the OE varied between 55 and $275 \mathrm{~mm}$ (Fig. 10A), and its width between 12 and $141 \mathrm{~mm}$ (Fig. 10B). The length of the uteri varied between 96 and $282 \mathrm{~mm}$ (Fig. 11A), and their width between 13 and $114 \mathrm{~mm}$ (Fig. 11B). During the developing phase (MP = III), a well defined group of follicles containing vitellogenic oocytes (mean follicle diameter between 11 and $58 \mathrm{~mm}$ ) of similar size accompanied by small follicles (mean follicle diameter between 1 and $12 \mathrm{~mm}$ ) were present in the ovaries $(\mathrm{OE}=3)$ from $102.8 \mathrm{~cm}$ total length. The epigonal organ was observed as substantial to rather insignificant (Figs. 1D \& 8E,F). Near ovulation (MP = III), the large follicles containing full-grown oocytes transformed to pre-ovulatory follicles which were ovoid, flaccid and vascularised (OE $=4$; Figs. 1D \& 9B), and the OE occupied nearly the entire cavity. No individuals in the process of ovulation were collected. The uteri were observed as nearly tubular to wide structures with thick walls (UT $=3$ ), with an open cervix $(\mathrm{CE}=2$; Figs. 1F, G \& 8E,F,J). After ovulation and during gestation, the short oviduct was no longer observable, and only the oviducal gland was distin-

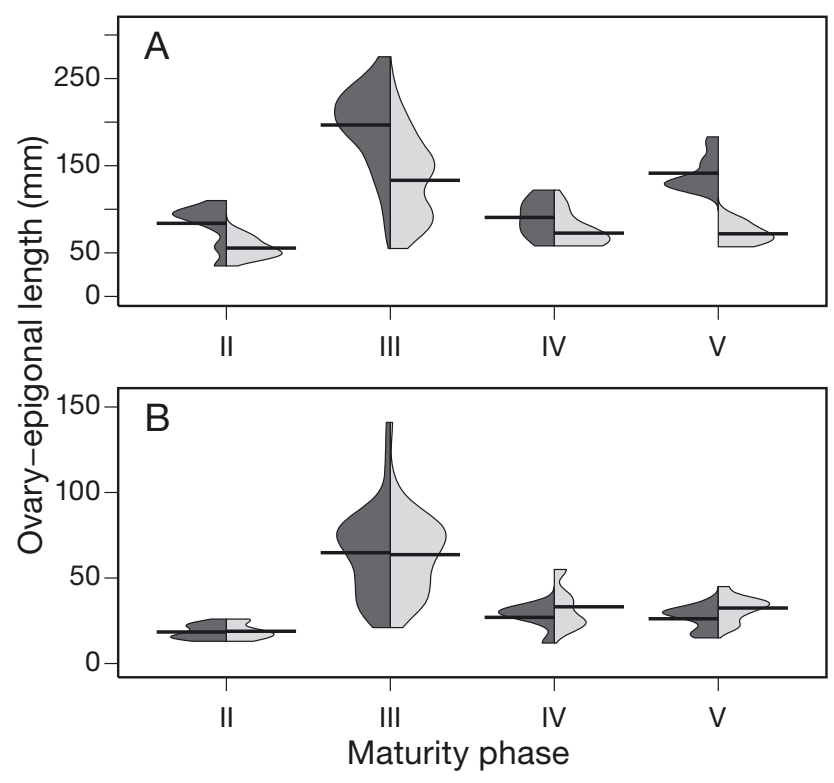

Fig. 10. Maturity phase (MP) versus density plots of the maximum left and right ovary-epigonal organ complex (A) length and (B) width for angel shark Squatina squatina. Horizontal bars represent the mean value per size distribution. MPs: II, subadult (immature); III, developing (mature); IV, pregnant (mature); V, post-partum (mature). For illustrations of the development and terminology of the major portions of the reproductive tract and MPs, see Fig. 8 and Table 2

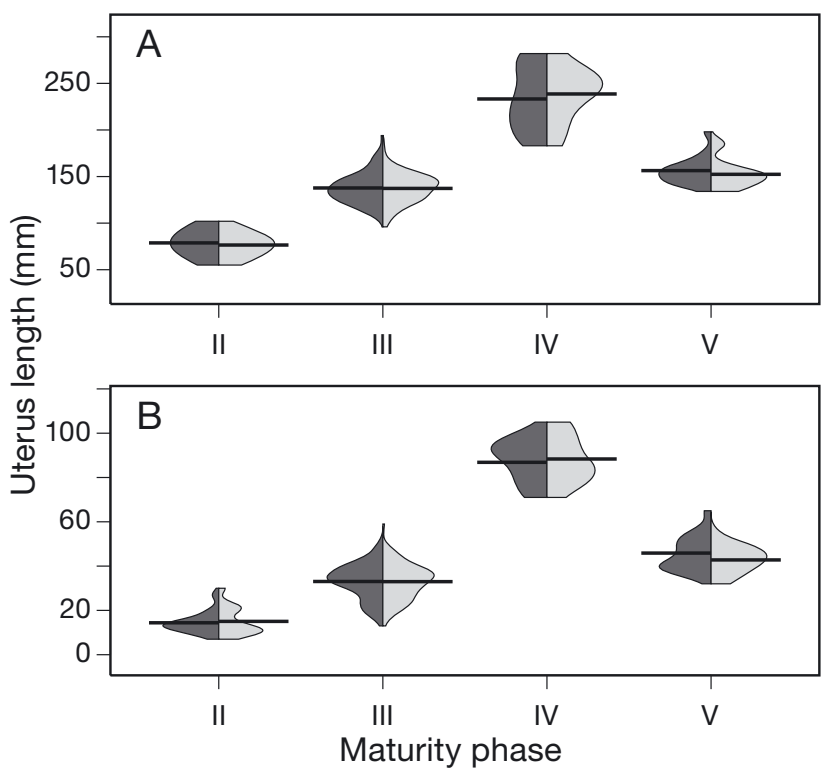

Fig. 11. Maturity phase (MP) versus density plots of the maximum left and right uterus (A) length and (B) width for angel shark Squatina squatina. Individuals with aborted or partially aborted uteri were excluded. Horizontal bars represent the mean value per size distribution. MPs as in Fig. 10. For illustrations of the development and terminology of the major portions of the reproductive tract and MPs, see Fig. 8 and Table 2 
guishable and was pushed towards the proximal part of the epigonal organ (Fig. 9C), indicating that this gland acts as a closing device preventing defluxing of the uterus content into the peritoneal cavity. Due to the presence of vascularised ova with indistinguishable or with recognizable embryos, in pregnant individuals $(M P=I V)$, the uteri were distended. The uterine walls were translucent and vascularised during early gestation and became thicker during the progress of gestation (UT $=4$ ), with the cervix closed $(\mathrm{CE}=3)$. No encapsulations of ova, and no uterine villi and indications of histotrophy, ovatrophy, adelphotrophy or placentatrophy were observed during gestation stages. The ovaries presented post-ovulatory, atretic and vitellogenic follicles $(\mathrm{OE}=5$; Figs. $1 \mathrm{D}, \mathrm{F}, \mathrm{G} \&$ $8 \mathrm{G}, \mathrm{H})$. During the post-partum phase, the uteri remained distended and vascularised $(\mathrm{UT}=5)$ or wide during the late stage ( $\mathrm{UT}=3$; Figs. $1 \mathrm{~F} \& 8 \mathrm{I}, \mathrm{J}$ ) with the cervix open $(\mathrm{CE}=2$; Fig. 1G). Similar to pregnant individuals, the ovaries presented post-ovulatory, atretic and vitellogenic follicles during the early stage of development. Towards the end of the development stage, the epigonal organ became predominant, and a group of small, dispersed follicles containing vitellogenic oocytes was formed in the ovaries ( $\mathrm{OE}=5$; Figs. 1D \& 8I-J). Two females did not fit in any of the described maturity phases. One individual was observed with scant medium-sized vitellogenic follicles, which were not accompanied by small ones, and a dominant epigonal organ. Another individual presented ovaries with atretic follicles together with small vitellogenic follicles, whereas there were no indication of a recent post-partum event found in the uterus or cervix. In both females, there was no indication of senescence or infertility because the reproductive tract was fully developed, with unknown activity.

\section{DISCUSSION}

\section{Male reproductive tract and conditions}

Both macroscopic and microscopic observations manifested periodic activity of the testes. The loss of all but the premeiotic stage of spermatogenesis in spent males indicates that males cannot mate year round. These changes in testes activity were also observed in the size, lobulation, vascularisation and colouration of the testes. To our knowledge, this is the only population of Squatinidae where seasonality of spermatogenesis was observed. Although periodicity in spermatogenesis is an important parameter for management of a species, few reproductive biol- ogy studies from other species in the genus Squatina have provided information about it. Parsons \& Grier (1992) suggested that absence of testicular and mating cycles might be apparent in areas that show little variation in environmental cues, such as the tropics and the deep sea. Presumably other parameters can also affect the testicular cycle based on Squatina species which inhabit the continental platform out of the tropics. Only $S$. squatina from the present study showed periodicity in testes activity, in contrast with species populating regions with a wider temperature range that are able to mate year round: the angular angel shark $S$. guggenheim from the San Matías Gulf (Awruch et al. 2008), the Pacific angel shark $S$. californica from California, USA (Natanson \& Cailliet 1986), and the Atlantic angel shark $S$. dumeril from the northern Gulf of Mexico (Baremore 2010) and the Argentina angel shark $S$. argentina from the Rio de la Plata estuary (Cousseau 1973), which showed no difference in the degree of lobulation and colouration of the testes.

No sperm were observed in the clasper glands, in contrast to the report for the South Pacific angel shark S. armata (Yáñez 1951). The sperm aggregates sampled from the seminal vesicle were helical. Coiled spermatozoa were also reported for $S$. dumeril (Baremore 2010), whereas Tanaka et al. (1995) found no gyres in the spermatozoa from the Japanese angel shark $S$. japonica. The observation is particularly interesting in view of the latest findings concerning the molecular phylogenetic and clock analysis of the genus Squatina, where $S$. squatina was assigned to the same geographic clade as $S$. japonica, and $S$. dumeril was assigned to a different clade (Stelbrink et al. 2010), indicating that spermatozoan morphology is therefore not necessarily consistent within clades.

In view of clearly distinguishable conditions, the partial calcification of claspers is ambiguous (e.g. Walker 2005, Segura et al. 2013); therefore, only 'fully calcified', 'functional' and 'not calcified' were described. In cases where more details of clasper development are required, length is a more accurate parameter because it can be clearly defined and measured (Segura et al. 2013). Additionally, Capapé et al. $(1990,2002)$ used clasper length to separate juvenile, subadult and mature phases. Segura et al. (2013) validated that the estimation of the breakpoints and slopes in the total length to clasper length relationship based on a segmented regression model (Muggeo 2003) can discriminate among these phases for $S$. guggenheim, among others, regardless of the life history strategy or the habitat of the species. 
The presence of fluid in the seminal vesicles was only useful to re-confirm the active phase and did not provide additional information compared with the condition of the testes. Estimating seminal vesicle fullness can be a useful parameter to distinguish maturity phases or to separate male active stages in certain species (ICES 2013). In the present study, estimating the vesicle fullness was equivocal and could be easily underestimated due to their small size and because of fluid that is forced out while manipulating the fish during capture or landing. Besides, the criterion of how to assign a 0,25, 50 or $100 \%$ filled seminal vesicle to an early or late stage is yet to be defined. Reasonably, an additional evaluation factor will be required to accurately determine this assignment. Notably, fluid extracted from the vesicles should be tested for fertility before any conclusions can be made (Natanson \& Cailliet 1986). Braccini et al. (2006) also considered the seminal fluid colouration and consistency but did not specify whether these characteristics are related to fertility or to a specific phase or stage.

\section{Histology of the TE}

In histological testes analysis from other species in the genus Squatina, a diametric pattern was reported for S. dumeril (Pratt 1988) and S. guggenheim (Awruch et al. 2008). Only late subadult $S$. squatina without a lobed appearance of the testes correspond to this pattern, whereas mature individuals could not be assigned to any of the described categories due to important differences in their development pattern and TE morphology compared with the description by Pratt (1988). The fold-like shape of the germinal zone in $S$. squatina is similar to the described diametric pattern. However, spermatocyst development in mature individuals mainly occurs over the cross-sectional height (ventral to dorsal) of the testes and not the width. Furthermore, the relative positions of the germinal zone and the epigonal organ are not constant over cross sections, and the germinal zone is rarely in the opposite centre of the epigonal organ. Together with the non-circular and non-uniform cross sections, a non-equidistant pattern of the different stages of spermatogenesis occurs with respect to the germinal zone, and in most cases, spermatocyst development is not across the full diameter of the testes in contrast to the original description of the pattern with corresponding testes morphology by Pratt (1988). In view of this observation, it can be concluded that the TE morphology of $S$. squatina does not correspond to any of the 3 patterns described by Pratt (1988). Indeed, this author suggested that a more complete survey might reveal more structural types. Likewise, Poulakis \& Grier (2014) described a slightly different testicular structure from the compound type for the cownose ray Rhinoptera bonasus. The above mentioned cases illustrate the variability in testis structure among elasmobranchs and highlight the need for adaptable staging techniques as more species are studied.

\section{Female reproductive tract and conditions}

In the present study, both ovaries were active, with vitellogenic follicles reaching ovulatory size, similar to the observations of Capapé et al. (1990) for the populations of $S$. squatina along the Tunesian Coast. Other species in the genus with 2 functional ovaries are the sawback angel shark $S$. aculeata (Capapé et al. 2005), the African angel shark $S$. africana (Bass et al. 1975), S. argentina (Vooren \& da Silva 1991), the smoothback angel shark $S$. oculata (Capapé et al. 2002) and the ornate angel shark S. tergocellata (Bridge et al. 1998). This characteristic, however, is not consistent in the genus, and several species have been reported with only the left complex active: $S$. argentina (Cousseau 1973), S. guggenheim (Vooren \& da Silva 1991, Sunyem \& Vooren 1997, Colonello et al. 2007, Awruch et al. 2008), the hidden angel shark S. occulta (Vooren \& da Silva 1991, Sunyem \& Vooren 1997), S. dumeril (Merriman \& Olsen 1949, Backus 1957, Hoese 1962, Baremore 2010) and S. californica (Natanson \& Cailliet 1986). Cousseau (1973) and Vooren \& da Silva (1991) revealed a different functionality for each studied distribution of S. argentina. Based on the observations of Cousseau (1973), the ovary functionality would be consistent within the geographic clades of the genus Squatina (Stelbrink et al. 2010), with the North and South America clade being different from the other clades. Paired ovaries in which the contralateral ovary may contain vitellogenic follicles that do not develop to pre-ovulatory follicles are thought to function in steroid production and are common in stingrays (Lutton et al. 2005).

The presence of egg candles in the uteri is another character that is not shared by all Squatinidae. Such encapsulations were not observed in the present study and have not been reported in most species of the genus. To date, only Sunyem \& Vooren (1997) observed a single egg candle surrounding all uterine ova for S. guggenheim and S. occulta. On the other hand, incomplete encapsulations were observed for 
S. oculata (Capapé et al. 1999, 2002) and S. aculeata (Capapé et al. 2005). Sunyem \& Vooren (1997) and Capapé et al. (2002) pointed out that this structure is very fragile and might not preserve its integrity during capture and handling, which might explain why it is not or only partially observed in certain species. Also, Capapé et al. (1999) hypothesised that the not entirely encapsulated ovum might be related to an evolutive phenomenon (e.g. the progressive extinction of the structure).

No nutrient source other than the yolk sac was observed in developing embryos, which confirms, similar to the findings of Capapé et al. (1990) for $S$. squatina along the Tunisian coast, the lecithotrophic viviparous reproductive mode as per Wourms (1981). Thus far, all reproductive biology studies of species in the genus Squatina have reported this mode.

The ovary conditions were differentiated based on the dominant development pattern of the follicles and on the general appearance of the OE by analogy with the methodology employed by Stehmann (2002) and WKMSEL2 (ICES 2013), rather than by introducing an arbitrary value for the largest or mean follicle diameter to determine different development stages, as applied by Walker (2005). This type of evaluation is satisfactory for ovaries of the external type with large oocyte development and with a punctuated ovarian cycle, as described by Koob \& Callard (1999), where follicle development and ovulation are coordinated processes leading to the ovulation of an entire group of similar- sized follicles. The follicle diameter for females that are near ovulation can be determined based on the observed follicle diameter distribution when pre-ovulating follicles are detected in the ovaries $(\mathrm{OE}=4)$ and based on the observed distribution range of mean follicle diameter.

In the present study, uterine width was not useful for elucidating between the different maturity phases or development stages within a phase, except for the pregnant phase with the post-partum and developing phase. This parameter, however, can provide quantitative information to support the qualitative assignment of maturity in certain species (ICES 2013, Poulakis 2013). Moreover, different maximum width distributions were observed between left and right uteri, illustrating the importance of specifying the measurement method and location, and the need to measure more than 1 uterine width parameter. Distinguishing virgin uteri was only possible by identifying their tubular shape. The few individuals observed in the late stage of development with nearly tubular uteri suggest that uterine width does not regress to its virgin condition after parturition. In general, none of the reproductive tract measurements was useful to discriminate between the maturity phases. Although the average values per phase were different on certain occasions, there was too much overlap in the size distributions between phases.

Several pregnant females were observed with partial abortions. This aspect has been reported for $S$. squatina by Risso (1810) and Couch (1865) and in the following other species from this genus: $S$. africana (Bass et al. 1975, Shelmerdine \& Cliff 2006), S. occulta and S. guggenheim (Sunyem \& Vooren 1997), $S$. tergocellata (Bridge et al. 1998), S. japonica (Nagasawa et al. 1998), S. aculeata (Capapé et al. 2005) and $S$. dumeril (Baremore 2010), as well as in other shark species, such as the piked spurdog Squalus megalops (Braccini et al. 2006). To prevent the underestimation of fecundity, it is important to detect partial abortion during gestation, which was achieved by observing the cervix condition $(\mathrm{MP}=\mathrm{IV}, \mathrm{UT}=4, \mathrm{CE}=2)$.

\section{Adequacy of recent general maturity scales}

The observed conditions in the present study were not directly adaptable to recent proposals of general maturity scales for fishes, which were based on studies of teleosts (Brown-Peterson et al. 2011) or, specifically for elasmobranchs, WKMSEL2 (ICES 2013). Essentially, the scale of ICES (2013) could not be adapted in the absence of a phase analogous to the developing phase as described in the present study. The work of Brown-Peterson et al. (2011) introduced the terminology of the maturity phases based on key steps within the reproductive cycle, which are defined by specific histological and physiological events of the gonads. This definition would make the terminology suitable for modification to fit a wide range of research needs. Subsequent works on elasmobranchs, i.e. ICES $(2010,2013)$, Paiva et al. (2011) and Serra-Pereira et al. (2011) based their scale on the guidelines of Brown-Peterson et al. (2011); however, the former scales did not appear to be uniform with the latter in some points. The developing phase, as assigned in the present study, encompasses gonadal growth through spermatogenesis or vitellogenesis towards active reproduction in mature individuals as part of the reproductive cycle, similar to the developing phase as described by Brown-Peterson et al. (2011). In contrast, WKMSEL (ICES 2010), Paiva et al. (2011), Serra-Pereira et al. (2011) and WKMSEL2 (ICES 2013) adopted the term 'developing' to the immature maturity assumption in individ- 
uals with an undeveloped reproductive tract which is, thus, not equivalent to the introduced terminology from Brown-Peterson et al. (2011).

Serra-Pereira et al. (2011) highlighted the need for further investigation of certain features of elasmobranch reproductive biology to fully adopt the proposed terminology from Brown-Peterson et al. (2011). Further difficulties in maintaining consistency in maturity assessment of elasmobranchs with the proposal from Brown-Peterson et al. (2011) are related to the adaptations of the reproductive organs in elasmobranch to internal fertilisation (Dodd 1983). Based on studies in teleosts, Brown-Peterson et al. (2011) only considered gonadal development based on histological and macroscopic analysis for the assessment, while in elasmobranch studies, the development of multiple reproductive organs was considered (e.g. Clark \& von Schmidt 1965, Stehmann 2002, Walker 2005, Poulakis 2013). This is of particular importance for species where maturity, or the complete development of the reproductive tract, is determined by primary characteristics other than the gonads, as observed in the present study and described for, e.g. blacktip shark Carcharhinus limbatus, bull shark $C$. leucas, tiger shark Galeocerdo cuvier (Clark \& von Schmidt 1965), piked spurdog S. megalops (Braccini et al. 2006), white-spotted skate Bathyraja albomaculata (Henderson \& Arkhipkin 2010) and more recently in $R$. bonasus (Poulakis 2013, Poulakis \& Grier 2014). The latter study observed that testicular development and the process of spermatogenesis started as early as embryonic development. Additionally, the direct adoption of the maturity scale and terminology as proposed by Brown-Peterson et al. (2011) would only be partially possible in this study. To contrast the described development phases with the corresponding histological features from Brown-Peterson et al. (2011), further histological analysis of the reproductive tract is required. This need for further analysis is particularly the case for the extra-testicular ducts and $\mathrm{OE}$ to distinguish the regenerating and regression phases as described by Brown-Peterson et al. (2011), if these phases are present in this species. On the other hand, the proposal of Brown-Peterson et al. (2011) is not adaptable to all teleosts because interspecific variations in fish oocyte development do not lend themselves to a standard terminology across all fishes (Grier 2012). Specific for elasmobranchs, the proposal of ICES (2013) includes a unique scale for viviparous species, despite the large number of reproductive strategies available within this group, until scientific evidence suggests otherwise (ICES 2013). Yet, specific characteristics from gonad development do not correlate directly with the reproductive cycles or modes (Koob \& Callard 1999), and consequently general scales based on appearances of the reproductive tract will likely benefit from considering the gonad development type apart from the reproductive mode. Notwithstanding, staging schemes need to be adaptable to species' variations that can account for the extreme reproductive diversity of fishes (Grier 2012), which indicates the need for the development of adaptable staging techniques. Additionally, Poulakis (2013) pointed out the importance of considering the methods used to assign maturity and the consistency of these across studies. Further discussion or revision of the above-mentioned difficulties and those difficulties already highlighted by Serra-Pereira et al. (2011) to fully adopt and standardise the proposed scale for teleosts of Brown-Peterson et al. (2011) to all elasmobranchs and that were not resolved in WKMSEL2 (ICES 2013) are beyond the scope of our study. Until then, it is preferable to adopt maturity assumptions that have been widely used in elasmobranch reproductive studies before these proposals to maintain uniformity with previous works.

The condition indices and subsequent scale were successfully adopted based on standardised method proposals for reproductive biology studies in elasmobranchs, which suggests that the employed classification model is potentially adaptable to other life strategy modes. The denomination of the maturity phases for the obtained condition indices followed the terminology of Stehmann (2002) or Walker (2005), except for the developing phase, for which these studies did not provide an outcome and which was taken from Brown-Peterson et al. (2011). The methodology adopted provides sufficient detail to describe the sexual development of the species, to calculate maturity and maternity ogives, to describe the reproductive cycle and to characterise the population structure. This level of detail contributes to a better understanding of the life history strategy that facilitates more effective species management. Species-specific descriptions will facilitate a more precise assessment of the sexual development stage compared with descriptions from general maturity scales, which should fit all particularities of viviparous or oviparous species, as proposed by Stehmann (2002), WKMSEL (ICES 2010) and WKMSEL2 (ICES 2013).

In conclusion, this study shows that assigning maturity phases in elasmobranchs while maintaining uniformity amongst other studies and species, in spite of the recent progress in proposals for the standardisation of terminology and criteria, remains chal- 
lenging. The latest proposals of general maturity scales for elasmobranchs are not yet a solid base to allow direct application of the maturity phases to all species. Furthermore, although these works state uniformity with the terminology and phases of a general maturity scale for teleosts, differences were found that must be resolved in future investigations. The adaptations of elasmobranchs to internal fertilisation compared with teleosts not only indicates that multiple organs of the reproductive tract of the former must be considered in maturity assessment compared with only the gonads of the latter, but also creates incompatibilities in maintaining uniformity in maturity assessments between teleosts and elasmobranchs. Therefore, this study sought to enhance the recent standardisation efforts by using a flexible classification system which is based on an ontogenic approach, providing a comprehensive description of the maturity phases of an under-studied species and genus, by complementing unambiguous descriptions and criteria and by highlighting the relevant difficulties in maintaining uniformity with the most recent proposals. Grier (2012) pointed out the need for species-specific macroscopic and microscopic techniques with adaptable staging systems given the reproductive diversity and variability of fishes, which do not allow a standard terminology across all species with different life history strategies.

Acknowledgements. This study was supported by the Shark Foundation. This manuscript was improved considerably by comments from Dr. Gregg R. Poulakis and 3 anonymous referees.

\section{LITERATURE CITED}

Awruch CA, Lo Nostro FL, Somoza GM, Di Giacomo E (2008) Reproductive biology of the angular angel shark Squatina guggenheim (Chondrichthyes: Squatinidae) off Patagonia (Argentina, southwestern Atlantic). Cienc Mar 34:17-28

Backus RH (1957) Notes on Western North Atlantic sharks. Copeia 1957:246-248

> Baremore IE (2010) Reproductive aspects of the Atlantic angel shark Squatina dumeril. J Fish Biol 76:1682-1695

Bass AJ, D'Aubrey JD, Kistnasamy N (1975) Sharks of the east coast of southern Africa: V. The families Hexanchidae, Chlamydoselachidae, Heterodontidae, Pristiophoridae and Squatinidae. Invest Rep Oceanogr Res Inst Durban 43:1-50

Braccini JM, Gillanders BM, Walker TI (2006) Determining the reproductive parameters for population assessments of chondrichthyan species with asynchronous ovulation and parturition: piked spurdog (Squalus megalops) as a case study. Mar Freshw Res 57:105-119

Bridge NF, Mackay D, Newton G (1998) Biology of the ornate angel shark (Squatina tergocellata) from the Great Australian Bight. Mar Freshw Res 49:679-686
Brown-Peterson NJ, Wyanski DM, Saborido-Rey F, Macewicz BJ, Lowerre-Barbieri SK (2011) A standardized terminology for describing reproductive development in fishes. Mar Coast Fish 3:52-70

Budker P (1958) La viviparité chez les sélaciens. Traite Zool 13:1755-1790

> Capapé C, Quignard JP, Mellinger J (1990) Reproduction and development of two angel sharks, Squatina squatina and S. oculata (Pisces: Squatinidae), off Tunisian coasts: semi-delayed vitellogenesis, lack of egg capsules, and lecithotrophy. J Fish Biol 37:347-356

Capapé C, Zorzi G, Seck AA (1999) New data on the eggs of angelshark, Squatina oculata Bonaparte, 1840 (Pisces: Squatinidae). Oebalia 25:53-60

Capapé C, Seck AA, Gueye-Ndiaye A, Diatta Y, Diop M (2002) Reproductive biology of the smoothback angel shark, Squatina oculata (Elasmobranchii: Squatinidae), from the coast of Senegal (eastern tropical Atlantic). J Mar Biol Assoc UK 82:635-640

Capapé C, Diatta Y, Seck AA, Guélorget O, Ben Souissi J, Zaouali J (2005) Reproduction of the sawback angeshark Squatina aculeata (Chondrichthyes: Squatinidae) off Senegal and Tunisia. Cybium 29:147-157

Clark E, von Schmidt K (1965) Sharks of the Central Gulf Coast of Florida. Bull Mar Sci 15:13-83

Colonello JH, Lucifora LO, Massa AM (2007) Reproduction of the angular angel shark (Squatina guggenheim): geographic differences, reproductive cycle, and sexual dimorphism. ICES J Mar Sci 64:131-140

Couch J (1865) A history of the fishes of the British Islands, Vol 1. Groombridge and Sons, London

Dodd JM (1983) Reproduction in cartilaginous fishes (Chondrichthyes). In: Rankin JC, Pitcher TJ, Duggan RT (eds) Fish physiology, Vol 9. Academic Press, San Diego, CA, p 31-95

Ebert DA, Stehmann MFW (2013) Sharks, batoids, and chimaeras of the North Atlantic. FAO Species Catalogue for Fishery Purposes, No 7. FAO, Rome

Engel KB, Callard GV (2005) The testis and spermatogenesis. In: Hamlett WC (ed) Reproductive biology and phylogeny of Chondrichthyes: sharks, batoids and chimaeras. Science Publishers, Enfield, NH, p 171-200

> Grier HJ (2012) Development of the follicle complex and oocyte staging in red drum, Sciaenops ocellatus Linnaeus 1776 (Perciformes, Sciaenidae). J Morphol 273:801-829

Hamlett WC (1999) Male reproductive system. In: Hamlett WC (ed) Sharks, skates, and rays: the biology of elasmobranch fishes. The Johns Hopkins University Press, Baltimore, MD, p 444-470

Hamlett WC, Knight DP, Pereira FTV, Steele J, Sever DM (2005) Oviducal glands in chondrichthyans. In: Hamlett WC (ed) Reproductive biology and phylogeny of Chondrichthyes: sharks, batoids and chimaeras. Science Publishers, Enfield, NH, p 301-336

Henderson A, Arkhipkin A (2010) Maturity index validation in the white-spotted skate Bathyraja albomaculata, from the Falkland Islands. J Mar Biol Assoc UK 90:1015-1018

> Hoese HD (1962) Sharks and rays of Virginia's seaside bays. Chesap Sci 3:166-172

ICES (International Council for the Exploration of the Sea) (2005) Report of the ICES advisory committee on fishery management, Advisory Committee on the Marine Environment and Advisory Committee on Ecosystems, 2005. ICES Advice, Vol 5. Available at http://iea.uoregon.edu/ indicators/Fish.Salmon.Baltic.Data.SeePage141.pdf (accessed 31 March 2015) 
ICES (2007) Report of the workshop on sexual maturity sampling (WKMAT). ICES CM 2007/ACFM:03. Available at www.ices.dk/community/Documents/PGCCDBS/WKM AT07.pdf (accessed 31 March 2015)

ICES (2010) Report of the workshop on sexual maturity staging of elasmobranchs (WKMSEL2). ICES CM 2010/ ACOM:48. Available at www.ices.dk/sites/pub/Publication\%20Reports/Expert\%20Group\%20Report/acom/201 0/WKMSEL/WKMSEL\%202010.pdf (accessed 31 March 2015)

ICES (2013) Report of the workshop on sexual maturity staging of elasmobranchs (WKMSEL). ICES CM 2012/ ACOM:59. Available at http://ices.dk/sites/pub/ Publication \% 20Reports/Expert\%20Group\%20Report/ acom/2012/WKMSEL/WKMSEL \%202012.pdf (accessed 31 March 2015)

ICES (2014) Report of the Working Group on Elasmobranch Fishes (WGEF), 17-26 June 2014, Lisbon, Portugal. ICES CM 2014/ACOM:19. Available at www.ices.dk/sites/ pub/Publication \% 20Reports/Expert \% 20Group \% 20 Report/acom/2014/WGEF/wgef_draft_2014.pdf (accessed 31 March 2015)

Kampstra P (2008) Beanplot: a boxplot alternative for visual comparison of distributions. J Stat Softw 28:1-9

Koob TJ, Callard IP (1999) Reproductive endocrinology of female elasmobranchs: lessons from the little skate (Raja erinacea) and spiny dogfish (Squalus acanthias). J Exp Zool 284:557-574

Lutton BV, St. George J, Murrin CR, Fileti LA, Callard IP (2005) The elasmobranch ovary. In: Hamlett WC (ed) Reproductive biology and phylogeny of Chondrichthyes: sharks, batoids and chimaeras. Science Publishers, Enfield, NH, p 237-282

Merriman D, Olsen YH (1949) The angel shark, Squatina dumeril, in Southern New England waters. Copeia 1949: 221-222

Morey G, Serena F, Mancusi C, Fowler SL, Dipper F, Ellis JR (2006) Squatina squatina. IUCN Red list of threatened species. Version 2013.1. Available at www.iucnredlist. org/details/39332/0 (accessed 31 March 2015)

> Muggeo VMR (2003) Estimating regression models with unknown breakpoints. Stat Med 22:3055-3071

> Nagasawa K, Tanaka S, Benz GW (1998) Trebius shiinoi n. sp. (Trebiidae: Siphonostomatoida: Copepoda) from uteri and embryos of the Japanese angelshark (Squatina japonica) and the clouded angelshark (Squatina nebulosa), and redescription of Trebius longicaudatus. J Parasitol 84:1218-1230

Natanson LJ, Cailliet GM (1986) Reproduction and development of the pacific angel shark, Squatina californica, off Santa Barbara, California. Copeia 1986:987-994

Paiva RB, Neves A, Sequeira V, Gordo LS (2011) Reproductive parameters of the commercially exploited deepwater shark, Deania calcea (Centrophoridae). Cybium 35:131-140

Editorial responsibility: Klaus Anger, Malente, Germany
Parsons GR, Grier HJ (1992) Seasonal changes in shark testicular structure and spermatogenesis. J Exp Zool 261: 173-184

> Poulakis GR (2013) Reproductive biology of the cownose ray in the Charlotte Harbor estuarine system, Florida. Mar Coast Fish 5:159-173

> Poulakis GR, Grier HJ (2014) Ontogenetic testicular development and spermatogenesis in rays: the cownose ray, Rhinoptera bonasus, as a model. Environ Biol Fishes 97: 1013-1029

Pratt HLJ (1988) Elasmobranch gonad structure: a description and survey. Copeia 1988:719-729

R Core Team (2014) R: a language and environment for statistical computing. R Foundation for Statistical Computing, Vienna. www.r-project.org

Risso A (1810) Ichtyologie de Nice, ou histoire naturelle des poissons du département de Alpes-Maritimes. F Schoell, Paris

Segura AM, Milessi AC, Vögler R, Galván-Magaña F, Muggeo V (2013) The determination of maturity stages in male elasmobranchs (Chondrichthyes) using a segmented regression of clasper length on total length. Can J Fish Aquat Sci 70:830-833

Serra-Pereira B, Figueiredo I, Gordo LS (2011) Maturation of the gonads and reproductive tracts of the thornback ray Raja clavata, with comments on the development of a standardized reproductive terminology for oviparous elasmobranchs. Mar Coast Fish 3:160-175

Shelmerdine RL, Cliff G (2006) Sharks caught in the protective gill nets off KwaZulu-Natal, South Africa. 12. The African angel shark Squatina africana (Regan). Afr J Mar Sci 28:581-588

Stehmann MFW (2002) Proposal of a maturity stages scale for oviparous and viviparous cartilaginous fishes (Pisces, Chondrichthyes). Arch Fish Mar Res 50:23-48

Stelbrink B, von Rintelen T, Cliff G, Kriwet J (2010) Molecular systematics and global phylogeography of angel sharks (genus Squatina). Mol Phylogenet Evol 54:395-404

Sunye PS, Vooren CM (1997) On cloacal gestation in angel sharks from southern Brazil. J Fish Biol 50:86-94

Tanaka S, Kurokawa H, Hara M (1995) Comparative morphology of the sperm in chondrichthyan fishes. Mem Mus Natl Hist Nat 166:313-320

Vooren CM, da Silva KG (1991) On the taxonomy of the angel sharks from southern Brazil, with the description of Squatina occulta sp. n. Rev Bras Biol 51:589-602

Walker TI (2005) Reproduction in fisheries science. In: Hamlett WC (ed) Reproductive biology and phylogeny of Chondrichthyes: sharks, batoids and chimaeras. Science Publishers, Enfield, NH, p 81-127

Wourms JP (1981) Viviparity: the maternal-fetal relationship in fishes. Am Zool 21:473-515

Yáñez PA (1951) Algunos datos y observaciones sobre nuestro pez ángel Squatina armata (Phil. 1887). Rev Biol Mar 3:150-153

Submitted: August 7, 2014; Accepted: April 13, 2015

Proofs received from author(s): May 11, 2015 